\title{
Вероника Симонова
}

Eduardo Kohn. How Forests Think: Toward an Anthropology beyond the Human. Berkeley: University of California Press, 2013. 288 pp. ISBN 978-0-5202-7611-6.

Вероника Симонова - научный сотрудник факультета антропологии Европейского университета в Санкт-Петербурге, руководитель Центра арктических и сибирских исследований (Социологический институт, РАН). Адрес для переписки: факультет антропологии ЕУСПб, ул. Гагаринская, ЗА, Санкт-Петербург, 191187, Россия.vsimonova@eu.spb.ru.

Книга Эдуардо Кона, профессора-ассистента Университета Макгилл, лауреата премии Грегори Бэйтсона (2014) «Как думают леса: К антропологии за пределами человека», изданная Университетом Калифорнии, представляет собой новый вклад в так называемую антропологию за пределами человека, написанную на основе этнографического материала, собранного среди представителей народа руна (Верхняя Амазонка). «Нечеловеческое»в философии и антропологии в первую очередь связывают с именами Анри Бергсона, Клода Леви-Стросса, Жиля Делёза и Феликса Гваттари. Кроме того, теоретическое течение, посвященное правам животных (animal rights) и культурным концепциям личности (personhood), так или иначе коррелирует с философией постгуманизма, в рамках которой написана книга Кона.

Здесь стоит также упомянуть, что понятие «nonhuman» - то есть «иной», «иночеловеческий» - достаточно широко используется в экологической антропологии, антропологии ландшафта, антропологии, предметом которой являются отношения человека и животного. Оно объединяет животных, растения, разнообразные природные объекты, рассматриваемые как акторы, наделенные способностью к взаимодействию друг с другом и с людьми. Этот подход не отводит человеку лидирующее место в природе, здесь человек рассматривается лишь как одно из многочисленных действующих лиц.

В «Журнале этнографической теории» HAU (Journal of Ethnographic Theory) в 2014 году был организован симпозиум в честь представляемой книги Кона, с последующими комментариями самого автора. Такое внимание к идеям Кона обосновано его новаторской позицией в области современной постгуманистической теории в антропологии. По-разному высказываясь о работе Кона, участники дискуссии тем не менее согласились с его выводом: жизнь человека с «иным» (human and nonhuman) есть процесс осмысления, проходящий рука об руку со знаками и одновременно сквозь них.

Книгу Кона «Как думают леса: К антропологии за пределами человека» я назвала бы «трудом о встречах за пределами запредельного». Экология «самости» (ecology of selves) представлена как процесс обучения языку других - животных, духов, а также белых людей, с которыми жители Верхней Амазонки делят свое пространство. Бруно Латур справедливо называет работу Кона «дипломатиче- 
ским измерением современной этнографии, в целом показывающим нам, как пройти мимо говорящих людей» (Latour 2014:269, 270).

Книга состоит из введения, шести глав и заключения. В первой главе Кон показывает нам, что процесс репрезентации - это не только что-то уникальное, но еще и нечто вписанное в другие «реальности». Он полагает, что символическое мышление во многом дестабилизировано другими знаковыми логиками, производимыми нечеловеческими акторами. Таким образом, наш человеческий мир, где репрезентации происходят посредством символического взаимодействия, если вспомнить Джорджа Мида (Mead 1934), обусловлен и контекстуализирован знаковыми реальностями, свойственными животным и иным «нечеловеческим акторам».

Вторая глава рассказывает о том, что все без исключения существа обладают талантом семиотического взаимодействия. Именно это умение наделяет жизнь способностью мыслить, делает живыми сами мысли, а «самость» (self) на основном уровне является продуктом семиотических логик.

В третьей главе автор сосредоточен на анализе этнографического материала. Он рассматривает вопросы, связанные со смертью и ее включенностью в жизнь. В повседневной жизни мы переживаем множество «маленьких смертей» и должны как-то строить на них свою жизнь. «Маленькая смерть» есть потеря состояния, отчуждение себя от себя же, находившегося в другом контексте, в других отношениях и с другими мыслями. Руна - охотники, и они признают, что те животные, на которых они охотятся, также имеют свою точку зрения, а, следовательно, и «самость». Если же человек теряет способность признавать «самость» в «иночеловеках», он становится «душевно слеп», и эта слепота ведет его к неизбежной гибели. Иными словами - непризнание «самости» другого существа, непонимание семиозиса другого склада чревато гибелью.

Пример радикальной слепоты души (как и радикального отчуждения самого себя) Кон увидел в одном из мифов руна. Этот миф (с. 127) повествует о демоническом существе juri juri, которое обернулось красивой белой женщиной и соблазнило молодого человека из руна. Молодой человек, понимая, с кем имеет дело, все же не стал уничтожать существо, а женился на женщине, которая, как ему казалось, полюбила его. В итоге јuri juri «отключило» чувствительность своего человеческого супруга и заживо пожрало его. Человек мог лишь констатировать факт собственной смерти (то есть осознавать то, что его съедают заживо) и стал объектом по отношению к самому себе прежде, чем умер.

Четвертая глава тоже этнографическая, здесь автор сфокусирован на языке, а точнее «пиджине», использующемся между людьми и «не-людьми». Глава посвящена тому, как Руна пытаются понимать иные логики, присущие нечеловеческим существам (животным, духам) и быть понятыми ими. Здесь речь не идет о распространении человеческой морали, скажем, на собак. Кон отводит читателя от «нарциссического антропоцентризма» и, напротив, говорит о комменсализме способе совместного существования различных организмов.

Выход за пределы собственной логики понимания мира, по мнению автора книги, носит лингвистический характер, Кон пишет о нем как о «трансвидовом 
пиджине». Как и в пиджине, использующемся в человеческом обществе, в трансвидовом пиджине грамматика уступает место иерархии видов. Те, кто неспособен учиться считывать логики иных, создавать и использовать трансвидовой пиджин, обречены на разрывы связей в собственной экологии «самости», что равнозначно смерти.

Пятая глава посвящена антропологическому значению «формы» как процесса становления жизни человека рядом с жизнями иных. Автор говорит о том, каким образом местные жители подстраиваются под различные паттерны лесной жизни и т. п. «Форма» рассматривается здесь достаточно абстрактно и не является ни продуктом разума, ни какой-либо механикой, не вписывается в дуалистическую картину картезианской философии и остается скрытой от привычной аналитической процедуры. Форма сама по себе пассивна, как и бытие в состоянии какой-либо формы. Активны лишь процессы, ее создающие. Этот тезис автор раскрывает на примере каучуковой экономики, демонстрируя одновременно иерархичность становления «формы» и ее зависимость от иерархии. Процесс отделения элемента от его экологии ведет к составлению новых связей и конечной формы в ее пассивном состоянии. В конце концов «форма» представляет собой нечто отличное от того, из чего она произошла.

Шестая глава раскрывает экологическое измерение «самости» колониальной истории, которая так живо интересовала Кона. Изображение «0т дикаря к христианину», украсившее организацию-представителя сообщества руна, наглядно демонстрировало становление человека: от нагого дикаря с копьем к цивилизованному дикарю-христианину, одетому сообразно европейским представлениям о подобающем костюме. Несмотря на то, что послание этого изображения отсылает к колониальным представлениям, Кон интерпретирует его иначе: подобное становление как бы было всегда для руна. Это состояние обретения новой формы лишь усилило «самость» народа руна, наделило его новой силой силой хищников. В действительности Руна считывают семиозис и хищников леса, и белых - тех же хищников, но пришедших из иной экосистемы. Кон вспоминает, что руна просили сфотографироваться с вещами Кона и других пришлых (и делали это с удовольствием), радовались символическому обретению новой силы через прикосновение к предметам, а также видели себя во сне в образе полицейского... Все это есть маленькие шаманские действия, работающие на становление и укрепление экологии «самости» народа руна, действия, направленные на обретение своего места между хищниками леса и хищниками иного мира - «колонизаторами».

Творческий поиск Кона вывел его на перекресток колониальной истории и экологии. Перед ученым стоял выбор: заняться ли интересной и неоднозначной колониальной историей региона, передающейся через устную традицию, или сосредоточиться на экологическом измерении изучаемого сообщества и культуры. Второй путь оказался ему ближе. Для Кона большую роль в размышлении над этнографическим материалом сыграл философ-семиотик Чарльз Сандерс Пирс, который ввел в научный оборот понятие фанерона - обобщенной целостности, каким-либо образом присутствующей в сознании безотноси- 
тельной реальности. Фанерон близок понятию «идея», однако первый не обязан быть связанным с чем-либо существующим (Peirce 1932). «Руна имели дело с другими видами коммуникативных миров, миров духов и животных. Это была их проблема, точно так же, как была проблемой для Пирса. Материал, с которым я работал, был семиотическим. Причина, по которой Пирс и Руна встретились - в том, что и он, и они созданы одним миром», как объяснил Кон (Golub 2014).

Филипп Десколя очень точно определяет теоретический поиск и метод Кона: «Это всецело новый подход к комплексу гибридного скопления [...], подход, основанный на тройственной экспертизе - обостренной этнографической чувствительности, выдержанном внимании к прагматике использования языка и великолепном улавливании экологических и биологических процессов в тропиках» (Descola 2014:267-268). В целом Десколя полагает, что подход Кона состоит в том, чтобы отойти от социального конструктивизма и дуализма. Используя «научные линиджи» - STS и структурализм, - Кон говорит о том, что мир является не игровой площадкой человека, но множественным набором различий между качествами и существами, которые могут быть системно организованы не вопреки, но благодаря этим различиям.

Кон опирается на семиотику как на качество, присущее жизни: «Семиотика это свойство жизни, семиозис всегда обрамлен в тело, он всегда включает в себя нечто большее, чем тело, а самости - есть продукты особых процессов, включающих отсутствие, будущее и рост так же, как способность принимать неверные решения» (с. 76). Именно поэтому для Кона все формы жизни являются не только продуктами знаков, результатами их взаимодействия, но и наделены способностью создавать знаки, а, следовательно, способностью их читать и учиться распознавать.

Тем не менее Кон выделяет людей в особую категорию и пишет обо «всем слишком человеческом» как о реальности, в которой присутствует символическое мышление. Он подчеркивает, что мораль присуща на этой планете лишь людям. Именно этот факт заставляет нас искать пути к пониманию других форм коммуникаций, свойственных «иным». Мораль - это что-то, что мы можем лучше понять с помощью «антропологии иных» (beyond the human); семиозис и мораль должны быть осмыслены в паре, поскольку мораль не может существовать вне символического (с. 135).

Подход Кона носит прикладной характер. Я бы назвала его подход «постгуманистическим колониализмом». Изучив семиозис «иных», человек будет способен контролировать их миры и с пониманием встраивать свою экологию самости в их экологии самости: «Я подобен серферу, который пытается плыть на гребне волны, и хочет узнать что-то истинное о волнах для того, чтобы обуздать их силу» (Kohn 2014:276).

Кон отходит от того, чтобы проецировать человеческое на иночеловеческое, пытается избежать «ловушки антропоцентризма». Ведь только так мы можем понять, что именно и каким образом делает нас такими, какие мы есть. Антропология позволяет ученым выйти за пределы собственной культуры и погрузиться в дру- 
гую реальность, другую культуру. Но сможет ли антрополог выйти за пределы человеческой природы, сменять культурные вселенные, путешествовать по ним и при этом не просто находить себя в «инокультурной» среде? Кон показывает, как это может осуществиться, каким путем стоит идти, чтобы попытаться заглянуть во вселенные совершенно иного порядка.

Считывание логики, которая не основана на принципах человеческого понимания (то есть на символическом мышлении), заставляет людей постигать мышление иного типа. Автор уверен, что и люди, и «иные» могут мыслить «по-научному»: то есть обладать способностью обучаться опытным путем.

Народ руна умеет считывать эти логики. В одном из этнографических очерков Кон рассказывает о том, как представители руна предупредили его о том, что спать в лесу можно только лежа на спине, лицом кверху, иначе проходящий мимо ягуар решит, что перед ним не спящий хищник, а мясо. Здесь логика ягуара как бы берется руна за основу: она определяет их понимание перемен состояния человека и открывает его сущность с точки зрения «иного». Одним действием человек меняет иерархию сущностей и превращается из равного в зависимого, из одухотворенного - в еду. По мнению Кона, понимать иные логики - это жизненный принцип руна. Неспособность к этому свидетельствует о «слепоте души», не дающей человеку посмотреть за пределы самого себя и своего вида. Такая неспособность ведет к разрушению «самости».

И в начале, и в конце книги Кон задается вопросами: что же такое «амазонский сфинкс» и почему нам так важна его загадка? Метафора (амазонский сфинкс) выбрана автором не случайно, поскольку это своего рода ключ к пониманию экологии «самости» руна. Кон переделывает известную загадку сфинкса на свой лад: каким будет ответ и как будет отличаться суть самого вопроса, если он задан «изза пределов» человеческого? (с. 222). Я бы переадресовала этот вопрос самому Кону: что происходит с нами, когда вопрос о нашей человечности (humanity) задается «иным»? Значит ли этот вопрос, что мы наделяем «иных» способностью считывать наши логики?

Но что такое «амазонский сфинкс» Кона? Я бы поняла это как «консенсус оборотничества», добровольное путешествие из собственного тела в иные тела, а также предоставление своего собственного тела иным. Сфинкс, как и «взгляд» ягуара, - приоритет автора.

Как пишет Десколя, о выводах Кона не просто необходимо «хорошо подумать», но «вместе с ними хорошо думать» (Descola 2014:270). И я предлагаю попытаться это сделать: осмыслить возможность жизни теории Кона за пределами амазонских лесов. Имея опыт длительных полевых исследований в Сибири и российской Арктике, занимаясь в частности вопросами отношений человека и природы в среде коренных и местных жителей этих регионов, я вижу большие возможности для жизни «организмов» теории Кона в северной антропологической экосистеме. Отношения человека и животного на Севере (как и вопросы формирования локального знания и его трансмиссии) могут обрести новое измерение, если «амазонский сфинкс» Кона обретет свою телесность в тайге и тундре. 


\section{СПИСОК ЛИТЕРАТУРЫ}

Descola, Philippe. 2014. “All Too Human (Still): A Comment on Eduardo Kohn's How Forests Think: Toward an Anthropology beyond the Human." HAU: Journal of Ethnographic Theory 4(2):267273.

Golub, Alex. 2014. "'An Anti-Nominalist Book': Eduardo Kohn on How Forests Think." Savage Minds: Notes and Queries in Anthropology, June 2. Retrieved August 28, 2017 (https://savageminds. org/2014/06/02/an-anti-nominalist-book-eduardo-kohn-on-how-forests-think/).

Kohn, Eduardo. 2014. "Further Thoughts on Sylvan Thinking." HAU: Journal of Ethnographic Theory $4(2): 275-288$.

Latour, Bruno. 2014. "On Selves, Forms, and Forces." HAU: Journal of Ethnographic Theory 4(2):1-6.

Mead, George Herbert. 1934. Mind, Self, and Society: From the Standpoint of a Social Behaviorist. Chicago: University of Chicago Press.

Peirce, Charles Sanders. 1932. Collected Papers of Charles Sanders Peirce. Vol.1, Principles of Philosophy and Elements of Logic. Cambridge, MA: Harvard University Press. 